\title{
Multiple layers of crises in Lebanon
}

\author{
Tam-Tri Le \\ Centre for Interdisciplinary Social Research \\ Phenikaa University, Hanoi, Vietnam \\ Written in Ho Chi Minh City on 11 October 2021
}

Lebanon is currently in a very difficult situation. Nationwide blackout is happening for several days due to major power plants running out of fuel [1]. A significant proportion of the Lebanese population live in poverty, and now they fear even more for their livelihood.

Long before this power crisis, Lebanon has been in a severe economic crisis, as its GDP dropped from 55 billion USD in 2018 to 33 billion USD in 2020 [2]. The economic crisis was mainly due to poor leadership and inadequate policy responses. The high inflation rate has been decreasing the value of people's income, and even middle-class families are now worried about food security.

On top of that, the COVID-19 pandemic is still another big problem. While the infection and death rate has decreased compared to the early months of 2021 [3], the disease is far from over and Lebanon's healthcare system is definitely in no good shape to take care of its patients at the moment.

Reflecting on the economic situation of Vietnam in the late decades of the $20^{\text {th }}$ century, my country also had to face many layers of crises at the same time [4]. A country weakened by prior problems is prone to even more risks, but if it can overcome the challenges, there will be many valuable insights for the future. Hopefully, with global cooperation, Lebanon can find its way out of the current situation as soon as possible.

\section{References}

1. Chulov, M. (2021, October 9). Lebanon hit by electricity outage expected to last several days. The Guardian. https://www.theguardian.com/world/2021/oct/09/lebanon-hit-byelectricity-outage-expected-to-last-several-days

2. World Bank. (2021, June 1). Lebanon Sinking into One of the Most Severe Global Crises Episodes, amidst Deliberate Inaction. World Bank. https://www.worldbank.org/en/news/press-release/2021/05/01/lebanon-sinking-into-one-ofthe-most-severe-global-crises-episodes

3. Worldometer. (2021, November 10). Lebanon COVID. Worldometer. https://www.worldometers.info/coronavirus/country/lebanon/

4. Chính, P. M., \& Hoàng, V. Q. (2009). Kinh tế Việt Nam: Thăng trầm và Đột phá. Nxb Chính trị Quốc gia, Hà Nội. 